\title{
Dış Kaynaklardan Yararlanma ve İşletme Fonksiyonlarına Uygulanabilirliği
}

\section{Bayram Şahin ${ }^{1}$}

\begin{abstract}
Özet
Dış Kaynaklardan Yararlanma (Outsourcing), özellikle 1980'li yıllardan sonra işletmecilik ve yönetim yazınında sıkça tartışılan ve farklı sektörlerde uygulama alanı bulan bir yönetim tekniği olmuştur. Dış kaynaklardan yararlanma (DKY) aslında tüm dünyada yıllardan beri uygulanan bir teknik olmasının yanında, tekniğin bir süreç olarak değerlendirilmesi ve komple bir uygulama altında incelenmesi nispeten yeni inceleme alanı olmuştur. DKY'nin bu kadar yoğun olarak tartışılmasında, uygulamada bazı işletmelerin çok başarılı olması ve diğer yandan bazı işletmelerin ise değişik nedenlerden kaynaklanan başarısız sonuçlarla karşılaşmalarının etkisi olmuştur.

Dış kaynaklardan yararlanma tekniği aslında birçok işletme fonksiyonuna uygulanabilir bir tekniktir. Ancak çoğu işletme ve kurum stratejik birkaç bölüm konusunda dış kaynaklardan yararlanmanın olumsuz neticeler doğurabileceğini ifade etmektedirler. Fakat uygulamada özellikle uluslar arası platformda, farklı ülkelerde hemen her işletme bölümünün DKY yoluyla fonksiyonlarını yerine getirdikleri görülmektedir. Bu çalışmanın amacı; DKY tekniğinin işletmecilik faaliyetlerinde hangi alanlarda uygulanabileceğinin belirlenmesi olarak ifade edilebilir. Şüphesiz çalışmada belirtilen alanların dışında da teknik farklı alanlarda uygulanabilir. Buradaki amaç, tekniğin uygulama alanlarının bir sistematik halinde belirlenebilmesidir.
\end{abstract}

Anahtar kelimeler: Dış Kaynaklardan Yararlanma, Temel Yetenek, Tedarikçi

\section{Outsourcing and Applicability to Operating Activities}

\begin{abstract}
Outsourcing has been a management strategy that found application areas in different sectors and has been discussed frequently in management and business literature especially since the 1980 's. Although outsourcing is a strategy which has been applied for years, the evaluation of the strategy as a process and the investigation of the strategy under a full application area is a new investigation area. Due to different reasons some establishment be unsuccessful and some establishments be successful in the application and these are the reasons of discussion of outsourcing densively.
\end{abstract}

The outsourcing strategy is a strategy that can be applicated in lots of

\footnotetext{
${ }^{1}$ Arş.Gör.Dr. Balıkesir Üniversitesi Turizm İşletmeciliği ve Otelcilik Yüksekokulu bayramsahin98@yahoo.com
} 
management function. But most establishment and institution express that outsourcing can cause some negative results in some startegic sections. But in the application especially in the international platform, in some countries it is seen that almost every establishment's section realizes its functions by outsourcing. The aim of this study is to determine the areas where outsourcing can be applicated in establishment's activities. Certainly the strategy can be applicated in different areas which are not defined in the study. The purpose here is to determine the application areas of the strategy in a systematic way.

Key words: Outsourcing, Core Competence, Vendor.

\section{GíRiş}

İşletmeler değişen iç ve dış çevre koşullarıyla mücadele edebilmek için farklı yöntemler uygulamaktadırlar. Rekabetin giderek artması işletmelerin mal ve hizmet üreterek tüketicilere ulaştırmalarını güçleştirmektedir. Çok sayıdaki işletme kendi ürettikleri mal ve hizmetleri ön plana çıkarabilmek için sektördeki diğer işletmelerle yoğun rekabet içerisine girmektedirler. İşletmelerin rekabet ortamından başarılı olarak çıkabilmeleri için her geçen gün yeni yönetim yaklaşımları ve uygulamaları ortaya çıkmaktadır.

Özellikle 1980'li yıllardan sonra, işletmecilik anlayışında yaşanan gelişmeler işletmelerini de birbirleriyle rekabet ederek müşteri tatmini ve dolayısıyla kar artışı beklemeleri sonucunu doğurmuştur.

$\mathrm{Bu}$ bağlamda işletmelerinin rekabetten sıyrılabilmeleri için uygulayabilecekleri bir yönetim yaklaşımı da dış kaynaklardan yararlanma (DKY) uygulamalarıdır.

Dış kaynaklardan yararlanma işletmelerin rakiplerine oranla daha iyi yaptıkları, temel yeteneklerin belirlenmesi ve geriye kalan yardımcı işlevler için konularında uzman işletmelerle sözleşmeler imzalayarak işletme faaliyetlerinin yürütülmesini esas alan bir yönetim yaklaşımıdır.

$\mathrm{Bu}$ çalışma işletmelerinin dış kaynaklardan yararlanma tekniğini hangi alanlarda uygulayabileceğinin tespitine yönelik bir literatür taraması şeklinde hazırlanmıştır. Konu ile ilgili yapılan araştırmalar sonucunda, işletmelerin dış kaynaklardan yararlanma uygulamasını, işletmelerin değişik iş süreçlerinde ne şekilde uygulayabileceklerinin tespit edilerek DKY'nin işletmeler üzerindeki etkileri belirlenmeye çalışılmıştır. Şüphesiz konu derinlemesine değerlendirildiğinde çalışmada belirtilen alanların dışında farklı süreçlerde de 
uygulanabileceği belirtilebilir. Ancak buradaki amaç genel bir değerlendirme yapılarak, uygulamada rastlanan örneklere değinmektir.

\section{DIŞ KAYNAKLARDAN YARARLANMANIN KAVRAMSAL ANALİZi}

DKY, temeli öz-yetenek (temel yetenek) kavramında yatan ve işletmenin öz-yetenek olarak kabul ettiği faaliyetler dışındaki işletme ihtiyaçlarını bir tedarik işletmesi vasıtasıyla temin etmesi olgusunu ifade eden bir kavramdır. Kavramın özellikle son yıllarda çok tartışılması, sektörler ve yönetim bilimciler arasında kavramın tanımı konusunda bazı çelişkilerin olduğunu ortaya koymaktadır.

Drucker' e göre, performansa doğrudan katkısı olmayan ikincil faaliyetlerin devre dışı bırakılması işletmelerin başarılarının anahtarı olacaktır. Gerçekten de bugün küreselleşme ve rekabetin getirdiği noktada belli bir faaliyet noktasına odaklanmak gerekmektedir. Piyasanın taleplerine ve beklentilerine zamanında doğru ve eksiksiz cevap verebilmek, standartlara uygun ürünler sunabilmeli, marka olabilmek için çevik olmak gerekmektedir. Bunu sağlayabilmek için dış kaynaklardan yararlanma çok uygun bir tekniktir (www.geocities.com,:2007)

İşletmenin temel yeteneği sahip olduğu iş gücü itibariyle uzman olduğu alanlar, rakipleri tarafindan taklit edilemeyecek derecede kendisine has olan bilgi ve beceriler, iş yapma usulleri, işletmenin temel yeteneğini ifade etmektedir.

İşletmelerin yoğun rekabet ortamında birçok faaliyete yönelmesi işletmenin sınırlı kaynaklarının, geliri maksimum seviyesine çıkarabilecek faaliyetler yerine daha az kazanç sağlanabilecek ya da kazanç sağlanamayacak faaliyet alanlarına kanalize etmesine yol açacaktır. Bu bağlamda işletmenin performansını en üst seviyelere çıkarabilmesi için faaliyetleri arasında en verimli olanını seçmesi akıllıca olacaktır. Böylelikle işletmelerin hem zaman açısından, hem diğer kaynakları açısından, yeteneklerini gerçekten iyi yaptıkları iş süreçlerine yönlendirmeleri işletmeler için bir kazanç kaynağı olacaktır. DKY anlayışının temelinde "İyi yaptığın işleri bünyende tut, geri kalan faaliyetleri tedarik et" felsefesi yatmaktadır. (Şahin, 2005: 6).

Kalite ve fiyat günümüzde tüketicinin satın alma kararlarını etkileyen en önemli parametrelerdir. Bir işletmenin bütün ürün ve süreçlerinde tek başına kaliteyi ve ucuz maliyeti yakalaması neredeyse olanaksızdır. Bir işletmenin bu 
standartta ürün ya da hizmetleri tek başına üretebilmesi çok büyük maliyetler gerektirecektir. $\mathrm{Bu}$ maliyetleri fiyatlara yansıttığı takdirde pazar payını kaybedecek ve işletmenin varlık sebebi olan karlılığa ulaşamayacaktır (Solak, 2002: 65).

Son y1llarda tartışılmakta olan trendler 10 yılı aşkın bir süredir dış kaynak kullanımına doğru yönelmişlerdir. Artan hareketlilik ve inançla örgütler; yeniden yapılanma, esneklik sağlama ve maliyetleri azaltma yoluyla geleneksel olarak örgüt içerisinde hazırlanan dış servisleri ve faaliyetleri daraltma yollarını aramışlardır (Fill ve Wisser, 2000: 43)

DKY, bir hizmetin alanının ve onun hedeflerinin sorumluluğunun bir dış tedarikçiye transfer edilmesi sürecidir. Uygulama tedarikçiyle kontrata (sözleşmeye) dayalı uzun dönemli bir ilişkiyi içerir (Aydınlı, 2001: 33).

Lacity ve Hirscheim DKY kavramını "basit bir ifadeyle bir tedarikçinin işletme çıktılarını daha kısa sürede ve daha düşük maliyetlerle işletme adına üretmesidir." şeklinde tanımlamışlardır (Lacity ve Hirscheim, 1993: 13).

DKY bazı fonksiyonların bağımsız üçüncü bir kuruluş aracıllı̆ı ile planlanması, yönetilmesi ve yürütülmesini sağlamaktır.

DKY, işletmenin kendisine rekabet avantajı sağlayan faaliyetlere odaklanmasına, kendi uzmanlık alanına girmeyen faaliyetleri ise bu konuda uzmanlaşmış organizasyon dışındaki işletmeler aracıllı̆ıyla gerekli kalite standartlarına uygun bir biçimde sağlanmasına olanak veren bir yönetim stratejisidir (Arslantaş, 1999: 11).

Netice olarak DKY; işletmenin mevcut olarak içeride ürettiği süreç veya hizmetlerin tedarikçi tarafından sağlanılması konusunda işletme ile bir veya daha fazla hizmet sağlayıcı arasında yapılan sözleşmeye dayanan uzlaşmadır. Örneğin, işletmelerin araştırma-geliştirme faaliyetlerini kendilerini yerine getirmeleri yerine bir danışmanlık veya araştırma işletmesiyle sözleşme imzalayarak tüm bu faaliyetleri işletme yerine tedarikçinin yerine getirmesine yönelik DKY anlaşması yapabilmektedirler.

\section{DIŞ KAYNAKLARDAN YARARLANMA KAVRAMININ ÖZELLIKLERİ}

Dünyada özellikle son yirmi yılda yönetim alanında yaşanan gelişmelere paralel olara karşımıza çıkan DKY, geniş bir inceleme alanı bulmuş ve işletmeler değişik amaçları doğrultusunda bu uygulamayı benimsemişlerdir. Yönetim literatüründe söz sahibi olan araştırmacılar yönetim alanında dış 
kaynaklardan yararlanmanın gerçekten verimliliği arttırmak ve yapılan işi desteklemek için tek bir yol olabileceğinden bahsetmişlerdir.

Son yıllarda tartışılan trendler, 10 yılı aşkın bir süredir dış kaynak kullanımına doğru yönelmişlerdir. Artan hareketlilik ve inançla örgütler; yeniden yapılanma, esneklik sağlama ve maliyetleri azaltma yoluyla geleneksel olarak örgüt içerisinde hazırlanan dış servisleri ve faaliyetleri daraltma yollarını aramışlardır (Fill ve Wisser, 2000: 43).

DKY ile ilgili özellikler şu şekilde sıralanabilir (Arslantaş, 1999: 14)

- DKY, uzun vadeli bir çözümdür,

- DKY, finansal kaynaklardan etkin bir şekilde yararlanılmasını sağlar,

- DKY, iş kaybı anlamına gelmektedir,

- DKY, işletmenin birçok faaliyetini dış kaynaklar aracıllğıyla sağlayabilmelerine yardımcı olmaktadır,

- DKY, "en iyi yapılan iş üzerine yoğunlaşma" anlamına gelmektedir,

- DKY, daha önce denenmiş bir süreci uygulayarak (benchmarking) hangi faaliyetlerin tedarikçi işletmelerden yararlanılarak gerçekleştirilmesi gerektiğine karar vermektir,

- DKY, gelip geçici bir tutku değildir, belirli planlar ve programlar dâhilinde uygulanması gerekir.

DKY kararından önce işletme içerisinde herhangi bir alanda faaliyetler performansın altında gitmektedir ve yönetimin yaptığı değişikliklere rağmen faaliyetler yoluna girmemektedir. Bunun üzerine aksayan departmanın faaliyetlerinin bir başka tedarikçiye verilmesi gündeme gelir. Bu aşamada önemli olan doğru tedarikçinin bulunmasıdır. Öncelikle üst yönetimin faaliyetlerde eksik olan işlerin neden yapılmadığını kanıtlaması gerekir. Tedarikçi seçilecek her alanda, tedarikçilerin üst yönetimin eğilimlerine uygun olup olmadığı araştırılmalıdır. Hedeflerin dizaynı, gerçekleştirilebilmesi açısından seçilecek tedarikçi en iyi şekilde analiz edilmelidir. Öncelikle aşağıdaki sorulara cevap alınmalıdır; (Greaver, 1999: 62,63).

- DKY için öncelikli amaçlar nelerdir?

- Neden bu amaçlar belirlenmiştir?

- Bu alanlarda verimlilik nasıl ölçülecektir?

- Hedeflenen alanlarda hangi aktiviteler gerçekleştirilecektir? 
- Hedef listede öncelikler var mıdır?

- Hangi aktivite seviyelerinde hedefler gerçekleştirilecektir?

- Belirlenen alanların tamamında mı yoksa belli alanlarda mı DKY uygulanacaktır?

- Ne tip tedarikçilerle işbirliği planlanmaktadır?

Yöneticiler dış kaynaklardan yararlanmayı kısa dönemli bir maliyet azaltma operasyonundan çok uzun vadeli stratejik bir yaklaşım olarak değerlendirmektedirler. Bu yaklaşım ile entelektüel derinlik kazanılması, yaratıcılık, güvenilirlik, kalite, katma değer ve küresellik gibi avantajlar kısa sürede elde edilebilmektedir. Sonuç olarak CEO, CFO ya da COO düzeyinde stratejik bir karar haline gelmektedir.

1997 y1lında Chief Executive dergisi ve Andersen danışmanlık şirketi tarafından 382 CEO üzerine yapılan bir araştırma verilerine göre, CEO’ları DKY'ye yaklaşım tarzlarının stratejik, taktiksel ya da hem stratejik hem de taktiksel mi olduğu ile ilgili sorulan soruya verilen yanıtların \% sonuçları aşağıdaki gibi çıkmıştır: (Greaver, 1999: 8).

Stratejik \%50 + Taktiksel\%47 + Her ikisi\%3= Toplam \%100

Örneğin; Nike üretim işlerinde stratejik DKY'yi başarılı bir şekilde kullanmış ve bu başarı Nike işletmesinin kendi öz-yeteneklerine ve sportif ayakkabıların dizaynı ve pazarlanmasına odaklanmasını sağlamıştır (Milgate, 2002: 327).

DKY, kararları gerekli kılan stratejik bir karardır. Amerikan Anonim Şirketi yetkilisi Leonard Stern'in de söylediği gibi "Risk olmadan, hepimiz birer ofis çalışanıyız ve çok az bir ücretle ofis çalışanı çalıştırabilirsiniz. Bir liderin, 2 ile 2'yi toplayıp sonuçta 5 olmasını sağlayacak bir vizyonunun olması şarttır" sözü DKY'ye yapılan stratejik bir yaklaşımı ifade etmektedir (Greaver, 1999: $10)$.

İşletmenin stratejik gelişiminin bir parçası olarak DKY kararı; son ürün pazarı, kabiliyet, maliyet, teknoloji ve tedarik pazar koşullarını içeren bir dizi faktörü göz önüne almalıdır (Jennings, 2002: 26).

\section{IŞLETMELERDE DIŞ KAYNAKLARDAN YARARLANMA TÜRLERI}

İşletme en iyi yaptığ 1 işi belirledikten ve onu dünyada en iyi yapan işletmeler arasına girdikten sonra kesinlikle bu yetkinliğini tedarikçilere 
bırakmamalıdır. Hatta onu korumak için önlemler almayı bile düşünmelidir. Ancak bunların dışında kalan ve rekabete doğrudan katkısı olmayan işler öncelikli olarak incelenmelidir. Birçok işletmede çekirdek olmayan yeteneklerin oran1 \%60-90 arasında olmaktadır(Corbett, 2005: 18).

Üretim alanı dışında kalan genel anlamda "entelektüel outsourcing" olarak tanımlanan yönetim, danışmanlık, bilgi ve teknolojik outsourcing'in kendine özgü özellikleri bulunmaktadır. Genelde satıcı alıcıdan daha fazla bilgiye sahip olmakta hatta alıcıya göre kendini daha yüksekte görmektedir. Ayrıca sonuçta istenen hizmet ya da ürünün tanımlanması zor olabilmektedir. Birçok durumda maliyetlerin önceden tahmini yapılamamaktadır (Outsourcing, 2004: 25).

DKY genellikle, mal ve hizmetlerin daha düşük maliyetlere tedarik edilmesi, kapasite artışı gibi nedenlerle başvurulan bir yönetim düşüncesidir. DKY uygularken tedarikçiler üzerinde kontrolün kaybedilmesi, problemlerin çözümlenmesinden ziyade, işletmeler için kâbus şeklini olabilmektedir. Bu nedenle uygulaması yapılacak tedarikçiler üzerinde sürekli bir kontrol mekanizması oluşturulmalıdır (Schwartz, 2002: 65).

DKY faaliyetleri giderek artan bir şekilde birçok işletme fonksiyonunu kapsar hale gelmiştir. Işsletmeler daha çok büyümeye katkıda bulunan karmaşık faaliyetleri tedarik etme eğilimindedir.

DKY uygulamalarında Türkiye'de en fazla rastlanan örnekler "personel taşıma servisi" ile "yemek temin hizmetleri”"dir (Dalay, 2001: 289). Türkiye'de özellikle inşaat sektöründe görülen "taşeron kullanma" veya imalat konularında "fason üretim" olarak bilinen işletmecilik uygulamaları da birer "dış kaynaklardan yararlanma” örneği olarak gösterilmektedir(Gökdere, 2000: 53). Bilgi teknolojilerinin yanı sıra günümüzde dış kaynak kullanım alanları artarak gelişmektedir. Dokümantasyon, bilgi yönetimi, temizlik, yemek, güvenlik, dağıtım, lojistik, parça üretimi, insan kaynakları, finans yönetimi, muhasebe süreçleri, endüstriyel bakım, emlak yönetimi, saha satış, pazarlama, telekomünikasyon, müşteri ilişkileri ve çağrı merkezleri gibi alanlar DKY'den etkilenmekte olup, birçok işletmede bu faaliyetler kısmen ya da bütünüyle dışarıdan tedarik edilmektedir(Bakan, 2004: 190).

DKY uygulaması Türkiye dışında da yoğun olarak görülmektedir. Özellikle gelişmiş ülkelerde tedarikçi işletme, alıcı işletmenin tüm sorunlarıyla ilgilenmektedir. Müşterilerinin kalite geliştirme, maliyet düşürme, örgütsel yapılarını geliştirme, personel eğitimi vb. konularda yardımcı olmakta hatta 
kredi desteği bile sağlayabilmektedir. Tedarikçi işletmenin bazı uzmanları alıcı işletmeye destek olabilmek amacıyla alıcı işletmenin bünyesinde onların ilgili insan kaynağıyla işbirliği içerisinde çalışmaktadırlar (Ertürk, 2000: 285).

Genellikle işletmelerin değişik iş süreçlerinde faydalandıkları ana alanlar aşağıdaki şekillerde görülmektedir. İşletmeler faaliyet alanlarına göre dış kaynak uygulamalarını farklılaştırıyor olsalar da DKY uygulamalarının birkaç başlık altında toplanabildiği söylenebilir.

\section{III.I. Yönetim ve Organizasyon Faaliyetleri ile Ilgili Dış Kaynaklardan Yararlanma}

Yönetim kavramı bir asırdan daha uzun bir süredir gelişstirilmekte olan bir kavramdır. Ekonomik bir amaca dayalı olarak kurulan işletmelerin parasal, sevk ve idare edilmesini ifade etmektedir (Ertürk, 2000: 5). Dış Kaynaklardan Yararlanmanin özünde yatan temel yeteneklerin belirlenmesi ve geriye kalan süreçlerin tedarikçilerden temin edilmesi kaynakların en optimal biçimde kullanılmasinı ifade etmektedir.

DKY işletme içinde sunulmuş olan hizmet ve/veya ürünlerin dağıtımını işletme dışı başka bir girişimci ile tedarik etme şekli olarak ta tanımlanmaktadır.

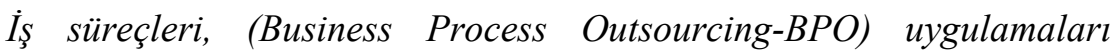
performansı veya kârlılı̆̆ iyileştirmek, global pazarlarda rekabetçi avantaj elde etmek ve nihayetinde hissedar değerini oluşturmak için ABD, Avrupa, Güney Amerika ve Asya Pasifik'teki birçok öncü şirket tarafindan yaygın olarak benimsenen yeni bir yönetim aracıdır(Bakan, 2004: 193).

Yarı hiyerarşik ve tam hiyerarşik yönetim yapısının kombinasyonu, dış kaynaklardan yararlanmada sadece kendi yeterliliklerini sürdürmeye değil aynı zamanda tedarikçilerinde teknolojik ve yeni yetenekleri öğrenmelerini, riski paylaşmayı ve sinerji elde etmelerine amaçlamaktadır(Kotabe ve Murray, 20045: 14).

Üretim alanı dışında kalan genel anlamda "entelektüel outsourcing" olarak tanımlanan yönetim, danışmanlık, bilgi ve teknolojik dış kaynaklardan yararlanmanın kendine özgü özellikleri bulunmaktadır. Genelde satıcı alıcıdan daha fazla bilgiye sahip olmakta hatta alıcıya göre kendini daha yüksekte görmektedir. Bazı durumlarda tedarikçi anlaşmada üstün konumda bulunabilmektedir (Outsourcing, 2004: 16). Genel ve idari faaliyetlerle ilgili dış kaynaklardan yararlanma kapsamına; ofis araç ve gereçlerinin dışarıdan temini, ofis dizaynı faaliyetlerinin dış kaynak sağlayıcılara devri, taşıma ve stoklama 
işlemlerinin dış kaynaklara devri, posta işlemleri ile ilgili dış kaynaklardan yararlanma, dahili işletme faaliyetleri ile ilgili dış kaynaklardan yararlanma ve bina bakımı ve temizlik işlerinin dış kaynaklara verilmesi girmektedir(Demir, 2004: 29).

III.II. Satış ve Pazarlama ile İlgili Faaliyetlerde Dış Kaynaklardan Yararlanma

İşletmeler diğer birçok faaliyet alanında olduğu gibi satış ve pazarlama faaliyetlerini de dış kaynaklardan yararlanma yoluyla temel yeteneğini satış veya pazarlama olarak belirlemiş olan tedarikçi işletmeler yoluyla temin edebilmektedirler.

İşletmelerin pazarlama ile ilgili faaliyetlerinde yoğunluğun reklâmcılık alanında gerçekleştiği görülmektedir. American Management Association tarafından 1997 yılında, üretici 619 işletme üzerinde yapılan araştırmaya göre, işletmelerin \%51'inin pazarlama faaliyetleri ile ilgili dış kaynaklardan yararlandığı sonucuna ulaşılmıştır (Greaver, 1999: 305).

DKY işletmelerin pazarlama faaliyetlerini etkili bir şekilde yerine getirebilecekleri bir uygulama olabilmektedir. İşletme tüm pazarlama faaliyetlerini yerine getirerek bir işletmeyle, DKY sözleşmesi yapılabilmektedir. $\mathrm{Bu}$ durumda işletmenin pazarlama sorumlusu ve tedarikçi faaliyet alanının pazarlama etkinliği devam ettiği sürece geçerli olacaktır. Departman oluşmadan, bir tedarikçi yoluyla tüm faaliyetlerini yerine getirebilmektedir. Profesyoneliyle, onun uzmanlığından faydalanabilmektedir. Böylelikle daha fazla yarar sağlayarak daha az ücret ödemesi yapabilmektedir(www.hildebrantcom, 2005).

İşletmeler, telefon pazarlamacılı̆̆g, satış temsilcileri, direkt/posta ile satış, tanıtım ve promosyon, tüketici hizmetleri, reklâm, halkla ilişkiler gibi faaliyet alanlarında diş kaynaklardan yararlanma yoluyla pazarlama faaliyetlerini yerine getirebilmektedirler.

Örneğin; spor ayakkabı piyasasında dünyanın en büyük ismi olan NIKE işletmesinin dış kaynaklardan yararlanması \%100 oranında gerçekleşmektedir. Spor ayakkabısı işinin hem üretim hem de pazarlama aşamalarında geçerli olmak üzere, modaya ve teknolojiye uygun olması için yüksek bir esnekliğe sahip olması gerekmektedir. Ayn1 zamanda üretim sonras1 pazarlama faaliyetleri de ön plandadır. Nike pazarlama konusunu temel yeteneği olarak 
belirleyerek spor ayakkabısı üretiminin \%100'ünü dış kaynaklardan yararlanarak yaptırmaktadır (Ataman, 2001: 339).

\section{III.III. Muhasebe ve Finansman İle İlgili Faaliyetlerde Dış Kaynaklardan Yararlanma}

Muhasebe ve finans alanında dlş kaynaklardan yararlanma, işletmelerin faaliyetlerinin sonuçlarının izlendiği, muhasebe kayıtlarının mevzuata uygun şekilde tutulmass ve yine ilgili prensipler doğrultusunda raporlanmasının, işletme bünyesinde yürütülmesi yerine, ilgili alanlarda uzman bir kuruluş tarafindan takibinin ve bu hizmetlerin yerine getirilmesini ifade etmektedir. Bu hizmetler tam zamanl ve yar zamanl olarak işletme ihtiyaçlarına göre planlanabilmektedir (www.insankaynaklari.com, 2005).

Dış Kaynaklardan Yararlanma açısından muhasebe ve finansman, diğer ifade edilen DKY türlerine göre daha az kullanma alanına sahip olmasına rağmen hizlı bir büyüme eğilimi içindedir (Greaver, 1999: 301).

Dış Kaynak Kullanımı hizmeti veren işletmeyle yapılan bir hizmet anlaşması faturalama ile ilgiliyse bu bazı belirgin hedefler içermelidir. Örneğin fatura başına ortalama maliyetin en aza indirilmesi veya faturaların zamanında ödeme yüzdesinin arttırlması gibi somut göstergeler ifade etmelidir. Ĕger mali ve finansal raporlama işinde bir dış kaynaktan yararlanıllyorsa belirlenmiş hedefler raporlamanın en sik şekilde sağlanması, raporlama periyotları, kapanış işlemleri, defteri kebirin kapatılması ve raporların üst yönetime sunulması konuların içermelidir (Aydın, 2002: 25-26).

Muhasebe ve finansman ile ilgili dış kaynaklardan yararlanma türleri; elektronik bilgi aktarmast, dahili büro faaliyetleri ve muhasebe faaliyetleri, (Greaver, 1999:301) finansal raporlama ve bütçe hizmetleri, muhasebe destek hizmetleri, personel ve bordro hizmetleri, uluslar arast muhasebe standartlarına göre raporlama, enflasyon muhasebesi, sabit kiymet takibi gibi çeşitlendirilebilmektedir (www.insankaynaklari.com, 2005).

\section{III.IV. Teknoloji ve Bilişim Sistemleri ile İlgili Dış Kaynaklardan}

\section{Yararlanma}

Dünyada DKY'nin en yaygın olduğu alanların başında bilgi teknolojileri (BT) gelmektedir. Uluslar aras1 "Outsourcing Institute" verilerine göre, 2003 yılında toplam dış kaynak kullanımının yüzde 52'sinin BT alanında olduğu görülmektedir (Bakan, 2004: 196). 
Bilgi teknolojileri(BT) alanında dış kaynaklardan yararlanma, daha önce organizasyonun iç kaynaklarından sağlanmakta olan mal ve hizmetlerin, tedarikçiler kullanılarak ve kontratlar imzalanması yoluyla, tedarikçiden sağlanması faaliyeti olarak tanımlanabilmektedir (Lacity ve Hirscheim, 1993:2). Uluslar arası araştırma şirketi IDC'nin verilerine göre, Türkiye'de BT dış kaynak hizmetleri 5 ana segmentte toplanabilmektedir. Bu segmentler şöyle stralanabilir: "Bilgi sistemleri altyapısının diş kaynaktan sağlanması (IS Outsourcing)", "Ağ ve masaüstü işletimi (NDOS)", "Uygulama Yönetimi (AM)", "ASP ad verilen uygulama hizmetleri sağlama" ve "IŞs süreçlerinin dış kaynaktan karşılanması (BPO) ”(Süzer, 2004: 9).

Bilgi sistemlerinde dış kaynaklardan yararlanma terimi dışsal ilişkilerin birçok farklı türü için kullanılmaktadır (Gökdere, 2000: 53).

- Veri tabanı yönetim sistemleri için dışsal danışmanlar kiralanmasinda,

- Bilgi sistem satıcılar yoluyla yeni bir sistemin geliştirilmesi, bakımı ve işletilmesinde,

- Organizasyonun içsel bilgi sistem departmanının; yazllım, donanim ve personel gibi tüm faaliyetlerin bilgi sistem satıcılarına transfer edilmesinde kullanılması olarak sayllabilmektedir.

Kaliforniya Üniversitesi ile CSC şirketinin birlikte gerçekleştirdiği bir araştırmada elde edilen bulgular, DOW Chemical, Philips, CAN Insurance ve Swiss Bank Corporation gibi birçok kuruluşun, önemli becerilere sahip bilişimcilerini elinden kaçırdıkları ortaya çıkınca çözüm olarak dış kaynak kullanımı düzenlemelerine başvurduklarını göstermiştir. Böylece bir yandan kendi elemanlarına becerilerini geliştirmeleri için yeni olanaklar yaratırken, bir yandan da kendi ellerindekinden çok daha zengin insan gücü kaynaklarından yararlanmaya başladıklarını ortaya koymaktadır (Bilgen, 1999: 1).

Bilgisayar sektöründe yaşanan rekabetin en büyük oyuncularından birisi olan IBM de dış kaynaklardan yararlanma uygulamalarına sıkça başvuran bir işletmedir. Toplam çalışan sayısı 100 binin üzerinde olan işletme, global veri ağları, ürün ve sistem destekleri konusunda dünya lideri konumunda bulunmaktadır. IBM'in, bilgi işlem alanındaki en son trendleri sergilemek amacıyla Londra'da Avrupa basın organlarına verdiği konferansta en temel trend olarak 'dış kaynaklardan yararlanmayı' göstermesi günümüz iş 
dünyasında dış kaynaklardan yararlanmanın önemini anlamamızda önemli bir gösterge olabilir.

Bu konuda örnekleri çoğaltmak mümkün olmaktadır. Royal Dutch Shell yılda \$ 1 Milyar karşılığ tüm Bilgi teknoloji çalışanlarını (IT), dış kaynaklardan yararlanma yöntemini kullanarak EDS üzerinden Hindistan'dan temin etmiştir. Aviva Sigorta 2,500 çalışanlık işlerini dış kaynaklardan yararlanma yöntemi ile Hindistan'a yönlendirmektedir. İngiliz Barclay Bankası 1,800 IT çalışanını işten ayırarak, ülke sınırları dışında dış kaynaklardan yararlanma yöntemini tercih etmektedir (Ofluoğlu ve Doğan, 2009, 158).

\section{III.V. İnsan Kaynakları Yönetimi İle İlgili Dış Kaynaklardan Yararlanma}

Müşteri memnuniyeti, maliyet kontrolü, gelir artışı gibi konular günümüzün önde gelen işletmelerinin gündeminde olan konulardır. Değişen piyasa ve rekabet koşulları, işletmelerin hedeflerine ulaşması için gerekli olan hız, değişim, sürekli iyileştirme ve gelişmenin yanı sıra bunları gerçekleştirecek olan "insan" faktörünün de önemini giderek daha fazla ortaya koymaktadır (Outsourcing(a), 2004: 34).

Insan kaynakları alanında diş kaynaklardan yararlanmanın gelişmesinde işletmelerde küçülme eğilimi, insan kaynaklart yöneticilerinin yeni rol ve sorumluluklar üstlenmesi, hizmet anlayışındaki değişim, global düzeyde faaliyet gösterme eğilimi nedeniyle, işletmelerin ev sahibi ülkelerdeki işgücünden yararlanma zorunluluğu, hızlı teknolojik değişim nedeniyle artan risk ve daha fazla esneklik arayışı, uzmanlaşmış yeteneklerin bulunmasında güçlüklerle karşılaşılması ve stratejik konulara daha fazla odaklanma gereksinimi çok etkili olmuştur (Bakan, 2004: 194).

Birçok işletmenin İnsan Kaynakları Departmanının, eğitim harcamalarından elde edilen verimi arttırmak için DKY'yi kullandıkları görülmektedir. Yapılan bir araştırma, işletmelerin \%32'sinin eğitim konusunda, dış kaynaklardan yararlandı̆̆ını ortaya koymuştur. Yine araştırmaya göre işletmelerin \%38'inin personel konusunda dış kaynaklardan yararlandiğını göstermektedir (Gilley, Greer ve Rasheed, 2004: 233).

Insan Kaynakları yönetimi ile ilgili DKY fonksiyonlar arasında,

Yönetici Tedariki, Bordro İşlemleri, Personel Seçme Süreci, İ̧̧ gören Kiralaması (Düzenli İşgücü), Geçici İş gören Temini, Fonksiyonel Eğitim Süreçleri, Üst Yönetim ve Yöneticilerin Eğitim süreçleri sayllabilmektedir 
(Greaver, 1999: 303).

Global olarak, insan kaynakları profesyonellerinin başlıca insan kaynakları süreçlerine harcadıkları zaman dă̆llımı incelendiğinde, "idari işler" başlığ altında "bordro" ve "genel idari işler" en çok zaman ayrılan IK süreçleri olarak dikkat çekmektedir. Bunu, "IK Strateji (IK politikalarının geliştirilmesi, IK planlaması, organizasyonel yapı/değişim yönetimi, endüstriyel ilişkiler, yönetim raporlaması) ve "Diğer çalışan danışmanlı̆̆l, sağllk/güvenlik, yabancı yönetici idari işleri, işten çıkarmalayrılma" süreçleri takip etmektedir (Outsourcing(b), 2004: 36).

İşletmeler, dış kaynaklardan iş gören temini yoluna, geçici ve sinırlı süreli iş gücü ihtiyacını gidermek için başvurmaktadır. Bu şekilde personel temini, özellikle işgücü maliyetleri ve devaml statüde personel çalıştırmanın bazı sakıncalarını taşımaması bakımından tercih edilebilmektedir. İş gören taşeronluğu adı da verilen bu yöntemde işletme; sosyal yardımlar, sigorta, vergi vb. ile işten çıkarma durumunda tazminat ödememekte, iş görenler için tek bir ücret ödemektedir (Karacaoğlu, 2001: 40).

\section{III.VI. Taşımacılık ve Lojistik Sektöründe Dış Kaynaklardan Yararlanma}

Geçtiğimiz yüzyılın son çeyreğinde yapılan araştırmalar 21.inci yüzyılın en hızlı gelişen sektörlerinin başında "Lojistik” sektörünün olacağını ortaya çıkartmıştır. Prof. Dr. Martin Christopher'in "Gelecekte kurumların rekabeti ürettikleri ürünlerde veya tüketilen ülkelerde değil, kullandıkları tedarik zincirleri arasinda olacaktır" ifade bu durumu kanitlamaktadır (Yıldıztekin, 2004:18). Ileri teknoloji üreten işletmelerin, ürettikleri ürünlerin kompleks ve çok değerli olması, farklı dağıtım kanallarının kullanılması, yapısal olarak hassas ve ürün ömrünün kısa olması lojistik gereksinimlerini önemli hale getirmektedir. Bu nedenle, global dağıtım merkezleri ağı, üretim tesislerinde tesis içi lojistiği, entegre depolama ve taşıma, entegre bilgi sistemleri alt yapısı, katma değerli hizmetler, taşıma ve müşteri yerinde montaj, lojistik süreçlerin her aşamasında izleme ve takip, satış sonrası hizmetler, geri dönüş lojistiği yedek parça dă̆ıtımı gibi alanlarda DKY önemli avantajlar sağlamaktadır (Bakan, 2004: 197). 
Tablo 1. Geleneksel Nakliye Yaklaşımı ile Dış Kaynak Kullanımının Karşılaştırılması

\begin{tabular}{|c|c|}
\hline Geleneksel & Dış Kaynak Kullanımı \\
\hline Standart & Müşteriye özel \\
\hline $\begin{array}{l}\text { Genellikle tek boyutlu, yalnızca } \\
\text { taşıma ya da yalnızca depolama }\end{array}$ & $\begin{array}{l}\text { Çok boyutlu taşıma, depolama, ambar } \\
\text { yönetimi birbirini tamamlar biçimde, } \\
\text { bütünleşik sistem yaklaşımı }\end{array}$ \\
\hline $\begin{array}{l}\text { Amaç nakliye masraflarının en aza } \\
\text { indirilmesi }\end{array}$ & $\begin{array}{l}\text { Hizmet kalitesi ve esneklik } \\
\text { gereksinimlerini de göz önüne alarak } \\
\text { toplam sahip olma maliyetlerinin en } \\
\text { uygun düzeye indirilmesi. }\end{array}$ \\
\hline 1,2 yıllık sözleşmeler & $\begin{array}{l}\text { Üst yönetim düzeyinde tartışılan daha } \\
\text { uzun süreli sözleşmeler }\end{array}$ \\
\hline $\begin{array}{l}\text { Daha kisitlı bir alanda uzmanlık } \\
\text { gereksinimi }\end{array}$ & $\begin{array}{l}\text { Daha geçiş kapsamlı lojistik uzmanlı̆̆ } \\
\text { ve analitikyetenekler gereksinimi }\end{array}$ \\
\hline Sözleşme görü̈şmeleri kısa sürer & Sözleşme görüşmeleri uzun sürer \\
\hline $\begin{array}{l}\text { İsletmeler arasındaki bă̆ daha zaylf, } \\
\text { hizmet să̆layıcı firmayı değiştirmek } \\
\text { daha kolay }\end{array}$ & $\begin{array}{l}\text { İsletmeler arasındaki băg daha } \\
\text { kuvvetli, hizmet săglayıcı işletmeyi } \\
\text { değiştirmek daha zor ve maliyetli }\end{array}$ \\
\hline
\end{tabular}

Kaynak: Doğan Mersin, Lojistikte Dış Kaynak Kullanımı, Yararları ve Dikkat Edilmesi Gerekli Noktalar.

http://www.bilgiyonetimi.org/cm/pages/yazArk.php?page=(Internet), 18.05.2005.

Lojistiği, nakliyeden ayıran en temel özellik, lojistiğin bir planlama ve organizasyon süreçlerinden oluşmasıdır. Lojistik; bir ürünün ham maddesinin üretildiği noktadan, tüketiciye kadar olan aşamadır. Taşımacıllk, depolama, depo içi üretim, ambalaj açma, ambalaj yapma, yeni ambalajlama gibi hizmetler, gümrüklü antrepo ve yurtiçi dağıtım hizmetlerini tamamı lojistik faaliyetler olarak ifade edilebilmektedir(Akdoğan, 2004: 40).

Yine çalışanların seyahatleri için, bir tedarikçiden faydalanılması, seyahatlerin organizasyonu, gibi faaliyetler DKY uygulamalariyla gerçekleştirilebilmektedir (Greaver,1999: 306). Bazı büyük işletmelerin bu anlamda bu fonksiyonu yerine getirebilmek için turizm işletmeleriyle tedarik 
anlaşmaları yaptıkları görülmektedir. Bu çerçevede satın alan işletme sadece talebini belirtmekte, anlaşma şartları çerçevesinde tüm ulaştırmaya ilişkin görevler tedarikçi turizm işletmesi (seyahat acentası) tarafından yerine getirilmektedir. Örnegin Alarko Holding, hiçbir şirketinin bünyesine araç satın almamakta, araç ihtiyacını "rent a car" işletmelerinde karşılamaktadır. Bir başka örnek; ABD'de faaliyet gösteren SW isimli işletme, ülkenin en büyük kablo üreticisi olan işletmedir, önceleri kendi bünyesinde taşıma faaliyetlerini yürütürken daha sonra, Schneider isimli taşımacılık işletmesiyle dış kaynaklardan yararlanma anlaşması yaparak, kendi öz yeteneği olan kablo üretimi işine odaklanabilmiştir.

\section{III.VII. İmalat Sürecinde Dış Kaynaklardan Yararlanma}

Imalat sanayi işletmelerinin önceleri bünyelerinde yürüttükleri bazı hizmetleri giderek yaygın bir şekilde dışsallaştırdıkları görülmektedir. Daha çok işletmelerin asl faaliyet alanlarında uzmanlaşma (temel yetenek) isteğiyle açıklanabilecek bu hizmetlerin dışsallaştırılması eğilimi, ürün ve hizmetler arasındaki dinamik bağların gelişmesinde son derece önemli olmaktadır (Bakan, 2004: 196). DKY kapsamında; ürün dizaynı, ürün montajı, paketleme, parça üretimi, parça dizayn gibi faaliyetler sayılabilmektedir (Greaver, 1999: 307).

Spor ayakkabı piyasasında dünyanın en büyük ismi olan NIKE işletmesinin dış kaynaklardan yararlanması \%100 oranında gerçekleşmektedir. Spor ayakkabısı işinin hem üretim hem de pazarlama aşamalarında geçerli olmak üzere, modaya ve teknolojiye uygun olmasi için yüksek bir esnekliğe sahip olması gerekmektedir. Ayn zamanda üretim sonrası pazarlama faaliyetleri de ön plandadır. Nike pazarlama konusunu temel yeteneği olarak belirleyerek spor ayakkabısı üretiminin \%100'ünü dıs kaynaklardan yararlanarak yaptırmaktadır (Ataman, 2001: 339).

ABD'nin 10 büyük sanayi işletmelerinden 3 'ü imalatlarının yarıdan fazlasını dış kaynaklardan yararlanma yoluyla gerçekleştirmektedir. Purchasing dergisine göre, ortalama bir işletmenin dışarıdan satın alınan parça, gereç ve hizmetlere harcadiğı para, 1995 'te dört yll önce düzeyin yaklaşık beş katına varmaktadır (Ataman, 2001: 339). Wolkswagen tarafindan satın alınan Rolls-Royce işletmesi dış kaynaklardan yararlanma

uygulamalarını sıkça kullanan bir işletmedir. Dünyanın en pahalı otomobillerini üreten Rolls Royce, kendi temel yeteneği olan motor, 
boya, deri ve ahşap işçilikleri dışındaki tüm faaliyetlerinde dış kaynaklardan yararlanmaktadır.

Oyak Renault, bir otomobilde yer alan tam 2000 parçayı dışarıdan bir tedarikçi ile üretmektedir. Bu parçalar 140 farklı işletmede yaptırılmaktadır. Sektörün önderlerinden Arçelik, kendi üretmediği parça ve bölümler için 350 farklı işletme ile çalışmaktadır. Konfeksiyon sektöründe çalışan 2.1 milyon kişiden, 1.4 milyonu tedarikçi olarak faaliyet gösteren işletmelerde görev yapmaktadırlar.

III.VIII. Güvenlik, Catering, Temizlik Hizmetleri İle İlgili

\section{Dış Kaynaklardan Yararlanma}

Geleneksel olarak dış kaynak kullanımı, belirli bir iş grubunun iyi tanımlanmış bir sözleşme çerçevesinde sırf bu işlere odaklanmış işletmelere devredilmesidir. Nitekim işletmelerde yemek, güvenlik, temizlik gibi işlerde dış kaynak kullanımı giderek artmaktadır (www.isguc.org, 2005).

Bilindiği üzere ABD'de yaşanan 11 Eylül olayı sonucu "Güvenlik" konusuna verilen önem artmıştır ve hizmetin profesyonel işletmelerden alınmasını zorunlu kılarak DKY uygulamalarını hızlandırmıştır. İşletmenin güvenliğinin emanet edileceği işletmeyi seçmek evlilik kararı vermek kadar önemli olabilmektedir. Bu seçimde şu kriterlere dikkat etmek gerekmektedir (Targaç, 2004: 18);

- Mevcut bir güvenlik projesi,

- Maliyet analizi,

- Referanslar,

- Personel yapısi, idari yapı,

- Deneyim,

- Denetim,

- Süreklilik, Esneklik, Yeterlilik,

- Ĕgitim.

Aynı şekilde günümüzde işletmelerin nadiren yemek ve temizlik hizmetlerini kendi bünyelerinde gerçekleştirdikleri görülmektedir. Genel itibariyle, işletmeler bu faaliyetleri kendi konularinda uzman, temel yetenek olarak kendilerine yemek, temizlik hizmetleri olarak belirlemiş olan işletmelerden tedarik etme yoluna gitmektedirler. İşletmelerin yanı sıra, kamu kuruluşlarının da bu hizmetleri özel işletmelerden tedarik ettikleri 
görülmektedir. Üniversiteler, Bankalar, Hastaneler gibi kurumların bu tarz faaliyetleri dış kaynaklardan tedarik ettikleri görülmektedir.

Tüm dünyada, 74 ülkede faaliyet gösteren uluslar arası bir işletme olan Sodexho, temel yetenek olarak catering alaninda faaliyet göstermektedir. Fakat, DKY'de yaşanan gelişmeler Sodexho'nun otelcilik sektörünü de hedef kitle olarak belirlemesini sağlamıştır. Amaç, ön büro hizmetleri dışında kalan ve back-ofis olarak nitelendirilen; güvenlik-denetim-kontrol-housekeeping, ortak alan bakımı, çamaşırhane, teknik bakım-onarım, peyzaj hizmetleri, havuz bakımı gibi alanlarda Dış Kaynak Kullanımı hizmeti vermeyi planlamaktadır (Outsourcing(c), 2004: 40).

Bunun yanı sıra konaklama işletmeleri çoğunlukla kendi bünyelerinde kat hizmetleri bölümüne bağlı olarak çalışan bir çamaşırhane bulundurmaktadır ancak bu çamaşırhaneler de DKY uygulaması kapsamında temizlik işletmelerine devredilebilmektedir. Çamaşırhane çalışanları, temizlik işletmesi tarafından sağlanmakta, fakat departman yöneticisi çoğunlukla konaklama işletmesinin üst yönetimine bağlı çalışmaktadır (Hacıoğlu, Karaman ve Şahin, 2008: 199).

\section{SONUÇ ve ÖNERILER}

Sonuç olarak işletmeler kar amaçlı kurulmuş ticari organizasyonlardır. $\mathrm{Bu}$ organizasyonların iş hayatını sürdürebilmeleri etkin çalışmalarına bağlıdır. Gerek iş performansı ve verimlilik, gerek müşteri memnuniyeti, gerekse ticari karlılığa ulaşamayan işletmelerin günümüz rekabetçi ortamında başarılı olmaları mümkün görünmemektedir. İşletmelerin yukarıda sayılan amaçlar doğrultusunda başarılı olmaları ise, yeni gelişmeleri ve trendleri takip edebilmelerine bağlıdır. Değişik organizasyonlar tarafından uygulanan ve farklı ülkelerde başarılı uygulamaları gözlenen trendlerden birisi de dış kaynaklardan yararlanma yönetim tekniğidir. Bu teknik birçok ülkede farklı sektörlerde çalışmakta olan işletmeler tarafından başarı ile uygulanmaktadır.

İşletmeler yapıları gereği bünyelerinde farklı süreçlerin gerçekleştiğ örgütlerdir. Yapısında karmaşık birçok sürecin gerçekleştirildiği organizasyonların işletmeciliğin her alt alanı ile ilgili temel yetenek geliştirmeleri nerdeyse olanaksızdır. İşletmelerin rekabetçi ekonomilerde daha esnek hareket edebilmeleri için, sürekli taşıdıkları atıl yüklerden kurtulmaları gerekmektedir. Kendilerinin temel yetenek olarak belirlemedikleri işleri diğer 
tedarikçilere devrederek, ancak uzman oldukları alanlarda, rekabet olanaklarının yüksek olduğu alanlardaki faaliyetlere yönelerek, hem performanslarını arttırabilirler, hem de karlılıklarını yükseltebilirler. Bu anlamda uygulanabilecek yeni yönetim tekniklerinden biriside diş kaynaklardan yararlanama olarak ortaya çıkmaktadır. Felsefe olarak dış kaynaklardan yararlanama uzun yıllardır aslında işletmeler tarafından uygulanmakta olan bir teknik olarak görülmekte olsa da, bu tekniğin bir süreç olarak e sözleşmeye dayalı olarak yürütülmesi açısından Türk işletmeleri açısından çok eski olmayan bir uygulama olduğu görülmektedir.

Başlangıçta işletmeler, dış kaynaklardan yararlanma uygulamasının, stratejik departmanlar ve fonksiyonlar açısından uygulanmasının riskli olduğu görüşünü benimsemiş olsalar da, uygulamanın olumlu etiklerinin somut olarak gözlenmesine müteakip, tüm alanlarda uygulanabilecek bir strateji olarak kabul edilmeye başlanmıştır. Önceleri, sadece temizlik, güvenlik, taşımacılık gibi alanlarda uygulanmakta olan strateji, günümüzde pazarlama faaliyetlerinde, satış faaliyetlerinde, üretim süreçlerinde, insan kaynaklarının temin edilmesi ve bu fonksiyonun yürütülmesinde yoğun olarak kullanılmaktadır. Hatta yöneticiler dış kaynaklardan yararlanmayı muhasebe ve finans alanlarında bile kullanmakta, DKY'yi bir finansal teknik olarak değerlendirmektedirler.

Günümüz rekabetçi şartlarının getirdiği en önemli değişiklerin başında ise, teknolojik gelişmelerin takibi gelmektedir. Birçok işletme açısından teknolojik gelişmelerin sürekli takip edilmesi ve işletme fonksiyonlarına uyarlanarak istenen etkinliğin sağlanması çok kolay olamamaktadır. Özellikle teknolojide ve bilgi sistemlerinde yaşanan gelişmelerin hızı işletmelerin kendi bünyelerinde kurdukları departmanları bile zorlamaktadır. Bir süre sonra, sadece bu iş için görevlendirilmiş birimler bile istenilen hedeflere ulaşılması açısından yeterli başarı gösterememekte, hatta çoğu zaman, bu şekilde yürütülen yapılanmalar maliyet açısından da büyük sıkıntılar yaratmaktadır.

Çalışmada anlatıldığı gibi uygun süreçler olarak planlandığı, öngörülerin detaylı olarak düşünüldüğü ve tedarikçilerin yeterli olarak araştırılıp, uzun vadeli stratejik analaşmaların yapıldığ DKY uygulamaları çok başarılı sonuçlar doğurmaktadır. 


\section{KAYNAKLAR}

Akdoğan, S. (2004), "Lojistik: Bir Planlama ve Organizasyon İşidir", Outsourcing Dergisi, 5: 39-42.

Arslantaş, C. C. (1999), "Yeni Bir Yönetim Stratejisi Olarak Dış Kaynaklardan Yararlanma ve İlaç Sanayiinde Faaliyet Gösteren Firmaların Dış Kaynaklardan Yararlanma Uygulamaları", Yayınlanmamış Yüksek Lisans Tezi, İstanbul Üniversitesi Sosyal Bilimler Enstitüsü.

Ataman, G. (2001), İşletme Yönetimi Temel Kavramlar\&Yeni Yaklaşımlar. İstanbul: Türkmen Kitapevi.

Aydın, E.T. (2002), "Muhasebede Dış Kaynak Kullanımı”, Yayınlanmamış Yüksek Lisans Tezi, Ankara Üniversitesi Sosyal Bilimler Enstitüsü.

Aydınlı, F. (2001), "Stratejik İnsan Kaynakları Yönetiminde Dış Kaynaklardan Yararlanma ve Bankacılık Sektöründeki Uygulamalara İlişkin Bir Araştırma”, Yayınlanmamış Yüksek Lisans Tezi, İstanbul Üniversitesi Sosyal Bilimler Enstitüsü.

Bakan, İ. (2004), Bir Yönetim Stratejisi Olarak Outsourcing, Çağdaş Yönetim Yaklaşımları, İstanbul: Beta Basım Yayım Dağıtım.

Bilgen, S. (1999), "Kamu Sektöründe Bilişim Hizmetlerinde Dış Kaynak Kullanımı", Bilişim / 99.

Corbett, M. F. (2005), "Etkili Bir İletişim Stratejisi Uygulamak (Managing The People Dimension)", Outsourcing, 9: 18-19.

Dalay, İ. (2001), Yönetim ve Organizasyon, İlkeler, Teoriler ve Stratejiler, Adapazarı: Sakarya Üniversitesi Yayınları.

Demir, Y. (2004), "İşletmelerde Dış Kaynak Kullanımı (Outsourcing) Uygulamaları", Kooperatifçilik, 146.

Ertürk, M. (2000), İşletmelerde Yönetim ve Organizasyon, İstanbul: Beta Basım Yayın Dağıtım.

Fill, C.; Visser, E. (2000), "The Outsourcing Dilemma: a Compasite Approach to the Make or Buy Decision", Management Decision, (38)1: 43-50.

Gilley, K.M.; Greer C.R.; Rasheed A.A. (2004), "Human Resource Outsourcing and Organizational Performance in Manufacturing Firms", Journal of Business Research, 57: 232-240.

Gökdere, H. (2000), "Bilgi Sistemlerinde Outsourcing", Gazi Üniversitesi Ticaret ve Turizm Eğitim Fakültesi Dergisi, 3: 50-63. 
Greaver, M.F. (1999), Stratejic Outsourcing-a Structured Approach to Outsourcing Decision and Initiatives. USA: American Management Association.

Hacıoğlu, N.; Karaman, S.; Şahin, B. (2008), Turizm İşletmelerinde Çağdaş Yönetim Teknikleri içinde Turizm İşletmelerinde Dış Kaynaklardan Yararlanma (Ed. Fevzi Okumuş, Umut Avcı) Ankara: Detay yayıncılık. Jennings, D. (2002), "Strategic Sourcing: Benefits Problems and a Contextual Model", Management Decision, 40(1): 26-34.

Karacaoğlu, K. (2001), "Dış Kaynaklardan Yararlanma Teknoloji ile İlgili Dış Kaynaklardan Yararlanmanın Türkiye'de Bankacılık Sektöründe Uygulamaları", Yayınlanmamış Yüksek Lisans Tezi, Niğde Üniversitesi Sosyal Bilimler Enstitüsü.

Kotabe, M.; Murray J. Y. (2004), "Global Sourcing Strategy and Sustainable Advantage", Industrial Marketing Management, 33: 7-14.

Lacity, M.C.; Hirscheim, R. (1993), Information Systems Outsourcing-Myths, Metephors and Realities (United Kingdom: John and Wiley \& Sons Ltd.)

Mersin, D., Lojistikte Dış Kaynak Kullanımı, Yararları ve Dikkat Edilmesi GerekliNoktalar.http://www.bilgiyonetimi.org/cm/pages/yazArk.php?p $\underline{\text { age }}=$ (Internet), 18.05.2005.

Milgate, M. (2002), "Alliances, Outsourcing and the Lean Organization", Journal of Organizational Change Management, 15(3): 327-330.

Ofluoğlu, G.; Doğan, Ş. (2009), "İşletmelerde Dış Kaynaklardan Yararlanma Yönteminin Organizasyon Yapısı İle Çalışma İlişkilerine Etkileri”, Kamu-İş Dergisi, 11 (1), 139-165.

Outsourcing Dergisi (a). (2004), "Sizin İşletmenizde Outsourcing'in Rolü Nedir?", Outsourcing, 6: 14-16.

Outsourcing Dergisi (b). (2004), "İnsan Kaynaklarında Dış Kaynaktan Faydalanma (HR Outsourcing)", Outsourcing, 4: 34-39.

Outsourcing Dergisi (c). (2004), “Sodexho'nun Outsourcing'de Yeni Hedefi Otelcilik Sektörü", Outsourcing, 4: 40-41.

Schwartz, A.; Ye, G. (2002), "Outsourcing-Control is the Key to Success", Former FDA, 6(2): 65-68.

Solak, M. (2002), "Dış Kaynaklardan Yararlanma (Outsourcing) ve İnsan Kaynakları Yönetimi Alanında Uygulanması”, Yayınlanmamış Yüksek Lisans Tezi, Marmara Üniversitesi Sosyal Bilimler Enstitüsü. 
Süzer, H.D. (2004), “Outsourcing'in Yıldızı Parlıyor", Siemens Business Service Digital, 12: 6-10.

Şahin, B. (2005), "İşletmelerde Dış Kaynaklardan Yararlanma ve Konaklama İşletmeleri Üzerinde Bir Uygulama”, Yayınlanmamış Yüksek Lisans Tezi, Balıkesir Üniversitesi Sosyal Bilimler Enstitüsü.

Targaç, İ. (2004), "Güvenlik Hizmetlerinde Outsourcing'in İncelikleri”, Outsourcing Dergisi. 2: 18-21.

Y1ldıztekin, A. (2004), "Outsourcing'in Vazgeçilemediği Sektörü: Lojistik", Outsourcing Dergisi. 3: 18-19.

http://www.e-cozumevi.com/Stratejik-Outsourcing.htm

http://www.geocities.com/ceteris_tr2/n_aktas.doc, İnternet, 13.03.2007

http://www.hildebrandt.com/Documents.aspx?Doc_1D=936_26K (Internet), 25.05.2005.

http://www.insankaynaklari.com (Internet), 21.04.2005.

http://www.insankaynaklari.com (Internet), 24.04.2005.

http://www.isguc.org/değișim yonetimi.php (Internet), 21.04.2005. 